\title{
LETRAMENTO DIGITAL E REMIX NO JOGO LEAGUE OF LEGENDS
}

\section{LETRAMENTO DIGITAL Y REMIX EN EL JUEGO LEAGUE OF LEGENDS}

\section{Letícia de Leon Carriconde ${ }^{1}$ Fabiana Poças Biondo ${ }^{2}$}

\begin{abstract}
Resumo: O trabalho investiga o letramento digital no jogo League of Legends (LOL), analisando a interação entre as multissemioses percebidas na produção de sentidos no e sobre este jogo. Em perspectiva interpretativista, reúne dados obtidos a partir do site oficial do LOL, de conversas com jogadores e interações em fóruns no site e no Facebook, de forma a discutir os modos de produção e consumo simultâneos no jogo. Problematizando a forma como o letramento remix aparece nessas práticas, verificamos que ele responde pela produção de sentidos e subjetividades entre os prossumidores e pela definição do jogo como um todo.
\end{abstract}

Palavras-chave: League of Legends; letramento digital; letramento remix.

Resumen: La investigación trata de la literacidad digital observada en el juego League of Legends (LOL), y analiza la interacción entre las multisemiosis percibidas en la producción de sentidos en y acerca de ello. Desde un abordaje interpretativista, reúne datos obtenidos en el sitio oficial de LOL, de conversaciones e interacciones en los fórums en ese sitio y en FaceBook, de manera que se pueda discutir los modos de producción y de consumo simultáneos en el juego. Problematizando la manera como la literacidad remix aparece en esas prácticas, pudimos verificar que ella es responsable por la producción de sentidos y de subjetividades entre los prosumidores y por definir el juego en su totalidad.

Palabras-clave: League of Legends; literacidad digital; literacidad remix.

\section{Introdução}

A internet 2.0 e as mudanças implicadas no modo como os indivíduos se relacionam, se informam e produzem significados já são uma realidade há mais de dez anos. Algumas dessas mudanças podem ser identificadas no jogo online League of Legends (doravante LOL), por meio do qual indivíduos interagem e se relacionam, encontram-se, criam grupos de amigos e/ou companheiros de time que lembram, por vezes, o time da rua que se encontrava para a clássica "pelada" no campinho do bairro, ou para o pique-esconde do final da tarde. Além disso, o relacionamento se expande para além do jogo, e podemos observar os membros de um time

\footnotetext{
${ }^{1}$ Aluna do curso de Letras Português-Espanhol da UFMS, bolsista de Iniciação Científica CNPq - PIBIC/20182019; e-mail: deleon.leticia@gmal.com

22 Professora da UFMS, Faculdade de Artes, Letras e Comunicação; e-mail: fabibiondo@gmail.com
} 
interagindo através de páginas do Facebook, grupos de WhatsApp, participando das mesmas manifestações políticas, organizando grupos de cosplayers etc. Descolando-se da interface do jogo e às vezes até do espaço virtual, vemos no LOL um exemplo da quebra de fronteiras realvirtual na atualidade.

Esse tipo de relação, inicialmente propiciado pela internet a partir de um interesse em comum - jogar uma partida -, pode gerar espaços de (re)criação cooperativa e transformadora, modificando hábitos e valores no âmbito de uma cultura de participação baseada não apenas no consumo, mas também na produção. Assim, a web 2.0, e neste caso o LOL, pode gerar dinâmicas que têm como foco a comunicação, o compartilhamento e a colaboração, o que permite, entre outras coisas, a transformação de usuários desses espaços - de consumidores passivos de informação a colaboradores ativos de uma cultura partilhada (DUDENEY et al. 2016).

Nesse cenário, jogos como o LOL convocam a pensar sobre o letramento digital em que jovens estão envolvidos na contemporaneidade, produzindo sentidos que se estruturam por meio de redes e envolvem vários letramentos, conforme destacou Buzato (2007; 2009). Nossa preocupação com esses jovens e seus letramentos, nas relações que constituem a cultura do realvirtual, justifica-se por nosso papel de professores de línguas, que precisam estar atentos à ampliação dos sistemas semióticos envolvidos no letramento digital, sendo este visto como “ainda mais poderoso e empoderador do que o letramento analógico" (DUDENEY et al 2016, p.18), em um mundo constantemente (re)desenhado pela presença da web 2.0.

Desse modo, situamo-nos no campo aplicado dos estudos da linguagem e nos propomos, neste trabalho, a analisar o letramento digital no e sobre o jogo LOL, a partir de dados recolhidos e organizados a partir de diversos espaços que, a nosso ver, se interligam pelo que já se pode denominar uma cultural do LOL - sites, redes sociais, conversas informais, encontros presenciais entre jogadores, entre outros. Tais espaços sucumbem as fronteiras entre o real e o virtual e nos permitem problematizar o modo como o letramento remix aparece nessas práticas. Para isso, valemo-nos de estudos sobre letramento digital, sobre letramento remix e semiótica social, sobretudo.

\section{Referencial teórico}

\subsection{Letramento digital e letramento remix}

A ideia de letramento digital envolve, antes de tudo, uma compreensão não-fronteiriça entre digital e analógico, como lembrou Buzato (2007). Para o autor, a principal característica 
desse letramento é justamente o hibridismo, o entrecruzamento entre múltiplos modos, múltiplos sistemas, múltiplas linguagens e múltiplas culturas:

[...] proponho uma visão dos letramentos digitais como redes complexas de letramentos (práticas sociais) que se apoiam, se entrelaçam, se contestam e se modificam mútua e continuamente por meio, em virtude e/ou por influência das TIC. (BUZATO, 2007, p.168)

Ainda conforme o autor, enquanto prática social, os letramentos digitais são transformados pelos contextos dos quais fazem parte, ao mesmo tempo em que os transformam, de forma dinâmica, "de modo que seus efeitos sociais e cognitivos variarão em função dos fatores socioculturais e finalidades envolvidos na sua apropriação" (BUZATO, 2007, p.168).

Temos, assim, que a riqueza de sistemas semióticos e o grande número de ferramentas e dispositivos digitais da atualidade, bem como a variedade de modos de interação (blogs, redes sociais, aplicativos, jogos, etc.), implicam muitos tipos de letramentos digitais. Dudeney et al. (2016) dividem os letramentos digitais em quatro grandes áreas de foco - a linguagem, a informação, as conexões e o (re)desenho -, organizando os letramentos, por eles observados, a partir do seguinte quadro:

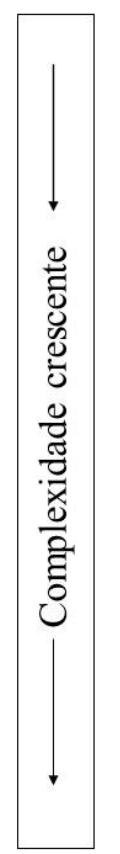

\begin{tabular}{|c|c|c|c|}
\hline $\begin{array}{l}\text { Primeiro foco: } \\
\text { Linguagem }\end{array}$ & $\begin{array}{l}\text { Segundo foco: } \\
\text { Informação }\end{array}$ & $\begin{array}{c}\text { Terceiro foco: } \\
\text { Conexões }\end{array}$ & $\begin{array}{l}\text { Quarto foco: } \\
\text { (Re)desenho }\end{array}$ \\
\hline $\begin{array}{l}\text { Letramento } \\
\text { impresso } \\
\text { Letramento } \\
\text { em SMS }\end{array}$ & & & \\
\hline $\begin{array}{l}\text { Letramento } \\
\text { em hipertexto }\end{array}$ & $\begin{array}{c}\text { Letramento } \\
\text { classificatório }\end{array}$ & & \\
\hline $\begin{array}{l}\text { Letramento } \\
\text { em multimídia }\end{array}$ & $\begin{array}{c}\text { Letramento } \\
\text { em pesquisa } \\
\text { Letramento } \\
\text { em informação } \\
\text { Letramento } \\
\text { em filtragem }\end{array}$ & $\begin{array}{c}\text { Letramento } \\
\text { pessoal } \\
\text { Letramento } \\
\text { em rede } \\
\text { Letramento } \\
\text { participativo }\end{array}$ & \\
\hline $\begin{array}{c}\text { Letramento em } \\
\text { jogos } \\
\text { Letramento } \\
\text { móvel }\end{array}$ & & $\begin{array}{l}\text { Letramento } \\
\text { intercultural }\end{array}$ & \\
\hline $\begin{array}{l}\text { Letramento em } \\
\text { codificação }\end{array}$ & & & $\begin{array}{l}\text { Letramento } \\
\text { remix }\end{array}$ \\
\hline
\end{tabular}

Quadro 01: Letramentos digitais (Fonte: DUDENEY, HOCKLY e PEGRUM, 2016, p. 21). 
Em negrito, no quadro 01, os autores destacam quatro macroletramentos, que envolvem vários outros letramentos (dispostos no quadro) em sua utilização, ao mesmo tempo em que são “influenciados" por eles (DUDENEY et al., 2016, p.31). Demonstram, assim, a conexão existente entre os letramentos digitas, pois, na prática, não podemos pensar que são utilizados de forma separada, tendo em vista a gama de sistemas semióticos e de focos de produção envolvidos no contexto de sua utilização.

O (macro)letramento em jogos "envolve habilidades linguísticas, multimidiáticas, espaciais, cinestésicas e outras" (DUDENEY et al, 2016, p.30), o que ressalta a importância de contar com os jogos como um espaço fértil para desenvolver e expandir outras habilidades, inclusive fora do espaço digital. Segundo os autores, estão presentes também nesse macroletramento o letramento impresso, utilizado na interação entre servidores, desenvolvedores e jogadores, relacionado às regras e termos de responsabilidade, o letramento em SMS, utilizado na interação entre os jogadores, nos chats e fóruns, bem como letramentos de outros blocos, como os letramentos pessoal e participativo, que fazem parte da grande área das conexões.

Outro (macro)letramento com foco na linguagem é o móvel, que implica habilidade de usar os dispositivos móveis e oportunidades de informação, comunicação e interação que eles oferecem, inclusive para a aprendizagem. A nosso ver, atualmente se entrecruza com o letramento em jogos, tendo em vista o grande número de aplicativos de jogos que podem ser baixados para dispositivos móveis, bem como com outros letramentos. Para interagir com o mundo através do telefone celular, por exemplo, o indivíduo precisa saber usar a escrita (letramento impresso) e, principalmente, o internetês (letramento em SMS), pois este traz um ganho de tempo na comunicação escrita nesse dispositivo, assim como ter desenvolvido o letramento pessoal e o letramento em rede, para citar somente alguns que consideramos entrelaçados.

No grupo dos letramentos digitais com foco nas conexões, temos o (macro)letramento pessoal, através do qual o usuário da internet constrói sua identidade virtual, produz uma representação sua dentro do aplicativo ou mídia em questão, se redesenha e usa essa identidade online para interagir de forma eficiente com seus pares, professores, com o mundo e em rede. Por ser o letramento envolvido na construção de uma persona virtual, ele se mostra essencial para o macroletramento em jogos, naqueles que contam com a necessidade de um avatar para serem jogados. Esse letramento também está relacionado com os protocolos de segurança que o usuário deve conhecer para proteger essa identidade online. Diretamente interligado a esse 
macroletramento, a nosso ver, está o letramento em rede, que reflete a habilidade de estabelecer redes de contato (sejam elas sociais ou profissionais), nas quais ocorre a interação, a comunicação e a troca de informações, e que conta com a importância de desenvolver uma reputação e a capacidade de influenciar outras pessoas através da rede, sabendo lidar com o macroletramento pessoal.

Com foco no (re)desenho, temos o letramento remix, de fundamental interesse para este trabalho. Tal letramento costuma ser definido como a habilidade de transformar um texto inicial em outro através da sua combinação com outros textos, criando novos sentidos para todos os textos que sejam usados nessa construção. Conforme Lankshear e Knobel (2008), o ato de remixar significa juntar artefatos culturais, manipulando-os e combinando-os de modo criativo, formando novos tipos e misturas. Os autores lembram que se trata de uma prática muito antiga, que constitui as culturas humanas e que tem se intensificado desde o final dos anos 80, bem como se reelaborando de forma mais sofisticada, em função dos mais recentes desenvolvimentos de tecnologias digitais.

Conforme Dudeney et al. (2016, p. 55), o letramento remix também se refere à habilidade de fazer com que os textos alcancem outras pessoas, identificado as melhores mídias a serem usadas no compartilhamento e a capacidade de "interpretar, responder e construir" com toda e qualquer remixagem que se encontre na rede. Muitas dessas remixagens são construídas coletivamente, sendo consideradas pelos autores "o ponto crítico do letramento participativo". Também sinalizam, para Dudeney et al. (2016), que os sujeitos se tornam mais hábeis no letramento remix à medida que mostram maior desenvoltura nos demais letramentos digitais, fazendo com que o remix seja o mais completo e complexo dos macroletramentos.

Como dito anteriormente, pensamos nos letramentos digitais como híbridos de modos, linguagens, sistemas e culturas. No letramento remix, observamos o confluir de todos os letramentos que fazem parte do conjunto de habilidades que possibilitam a construção de sentidos. Pelo remix, além de construir sentido, sujeitos transformam designs e os lançam de volta, na prática social e nos contextos em que estão imersos, ou em outros que possam dessa nova leitura se aproveitar, (re)criando matéria prima para um novo redesenho.

Para Lankshear e Knobel (2008), são os letramentos digitais relacionados às tecnologias contemporâneas que têm possibilitado a produção de remixes até mesmo em casa, a partir de uma variedade de mídias e formas culturais. Segundo esses autores, isso tem fortalecido uma "cultura de remix", que permite misturas diversas e intermináveis entre técnicas, conteúdos, gêneros e idiomas, bem como nos evoca a repensar questões legais, educacionais e culturais. 
Em direção semelhante, Manovich (2007), Eschenfelder e Casweel (2010), Stanovsky (2017), entre outros, pontuaram a cultura remix como a predominante a partir dos anos 2000 e como um truísmo o fato de que vivemos nessa cultura. Stanovsky (2017), referindo-se a uma “cultura e política remix”, caracteriza a prática de combinação entre conteúdos de uma mídia que já estão disponíveis (sejam filmes, músicas, dados da internet em geral, entre outros) e trabalhos midiáticos "novos" (reconstruídos, remixados). O autor destaca, ainda, a ampla gama de terminologias que são, atualmente, observadas juntamente com remix, a saber: colagem, amostra, bootleg, mashup, bricolagem, sampling, arte recombinante, etc.

De todo modo, para Stanovsky (2017), a remixagem é um campo de produções sempre aberto, que envolve multiplicidade e heterodoxias, configurando, em última instância, uma forma de se repensar a unicidade epistemológica. Nessa direção, acreditamos que o letramento remix seria, de fato, uma "categoria aberta", para usar a expressão do mencionado autor, um campo no qual se conectam outros letramentos por meio da criatividade, da recriação e da ressignificação. Pensando na dinâmica atual de produção de significados e rede de informações, tal letramento evoca a composição multissemiótica dessa dinâmica, e nos leva a pensar nas relações entre escrita-imagem às quais nos dedicamos por via da Semiótica Social, na seção a seguir.

\subsection{Escrita-imagem na perspectiva da Semiótica Social}

A pluralidade dos modos de produção de significados aparece na ideia de multimodalidade de Kress (2010) e em seus estudos da Semiótica Social. Para o autor, o sujeito utiliza muitos sistemas semióticos para produzir sentido em suas relações com o entorno, em relação com os modos e sistemas de uma comunidade social e cultural específica. Em parceria com Van Leeuwen, o autor explora a ideia de "potencial" semiótico, que tem a ver com o que se pode dizer e através de qual meio, mostrando que tal noção é definida por meio dos "recursos semióticos disponíveis para um indivíduo específico em um contexto social específico" (KRESS;VAN LEEUWEN, 2006, p. 9) ${ }^{3}$.

Para Kress e Van Leeuwen (2006), a relação existente entre visual e verbal é de complementação, a qual se relaciona com a ideia de potencial semiótico mencionada e pode ser pensada a partir da Semiótica Social. Nesse campo, imagens são tidas como representações de

\footnotetext{
${ }^{3}$ Nossa tradução para: by the semiotic resources available to a specific individual in a specific social context".
} 
formas de existir no mundo e podem ser analisadas a partir de duas estruturas representacionais, bem distintas uma da outra: a estrutura narrativa e a estrutura conceitual.

A estrutura narrativa representa acontecimentos "desdobráveis, processos de mudança, arranjos espaciais transitórios"4 (KRESS;VAN LEEUWEN, 2006, p. 79), na qual vetores ligam os participantes/elementos e representam a ação, ou seja, representam a existência do actante de forma dinâmica e em relação ao outro e a seu espaço/tempo. Já a estrutura conceitual representa seus "participantes em termos de sua essência mais generalizada e mais ou menos estável e atemporal, em termos de classe, estrutura ou significado" ${ }^{5}$ (KRESS;VAN LEEUWEN, 2016, p.79), quase como uma caracterização física e de caráter, sem contexto de tempo ou relação com o outro.

$\mathrm{Na}$ estrutura narrativa, alguns elementos são particularmente interessantes para nossas análises. Dos muitos processos observados nessa estrutura, os agentivos de ação transicional bidirecional serão abordados por sua possibilidade de leitura no LOL, pois subentende participantes/elementos agentes, ou, para os autores, "atores", aqueles que podem ser origem dos vetores de ação, que realizam uma ação. Tal ação acontece entre os participantes/elementos de forma bidirecional, por isso chamados pelos autores de interatores. Os vetores são linhas imaginárias, subentendidas na leitura, que conectam os participantes da imagem, através de ação e reação/respostas sucessivas, que acontecem simultaneamente.

Ainda nos processos descritos por Kress e Van Leeuwen (2016) que envolvem ação (agentivos), também podem ser encontradas representações de ação projetivas que, diferentes da anterior, possuem um vetor na forma de um balão de diálogo ligando os interatores (processo verbal), ou de pensamento (processo mental), como os comumente encontrados em histórias em quadrinhos. Ressaltamos que os autores se referem a imagens estáticas, pois, no caso de vídeos, o processo verbal acontece na forma de diálogo entre os elementos participantes, e o processo mental também pode aparecer como um diálogo interno ou com imagens com efeitos que façam o espectador perceber que se trata de um processo interno do personagem em questão.

$\mathrm{Na}$ estrutura narrativa, podemos também encontrar, além de processos, participantes/elementos secundários, que não são essenciais para o entendimento do que está sendo representado, embora sua omissão acarrete perda de informação - são as chamadas

\footnotetext{
${ }^{4}$ Nossa tradução para: "unfolding actions and events, processes of change, transitory spatial arrangements",

${ }^{5}$ Nossa tradução para: "participants in terms of their more generalized and more or less stable and timeless essence in terms of class, or structure or meaning.,
} 
“circunstâncias". Os autores descrevem a "circunstância da locação”, representada pelo cenário, que é reconhecível, pois na imagem os participantes/elementos se sobrepõem a ele, que aparece de forma às vezes desfocada e esmaecida; a "circunstância dos meios", que se refere ao instrumento causador da ação representada pelo vetor; a "circunstância de acompanhamento", que representa um participante/elemento que acompanha outro, sem a necessidade de um vetor, de uma linha imaginária subentendida e que os conecte.

Nas estruturas conceituais, encontramos, de acordo com os autores, uma subdivisão em estruturas de classificação e estruturas de análise. As estruturas de classificação podem ser de taxonomia encoberta ou taxonomia evidente. Na primeira, que nos interessa mais especificamente aqui, os elementos classificados são chamados "subordinados", apresentados de maneira ordenada espacialmente de forma simétrica, vertical e horizontal, demonstrando sua igualdade. Entre eles não existe uma relação aparente, baseada em um fator dito natural.

Com relação às estruturas de design que analisam a postura do espectador, os autores determinam como um de seus critérios a relação entre os participantes e o produtor da representação visual. A relação que nos interessa é a que considera os participantes como interativos, além das ações que eles realizam uns com os outros, através das imagens.

\begin{abstract}
Os participantes interativos são, portanto, pessoas reais que produzem e dão sentido a imagens no contexto de instituições sociais que, em diferentes graus e de maneiras diferentes, regulam o que pode ser "dito" com imagens, como deve ser dito e como deve ser interpretado. Em alguns casos, a interação é direta e imediata. Produtor e espectador se conhecem e estão envolvidos em interação cara-a-cara [... $]^{6}$ (KRESS; VAN LEEUWEN, 2006, p. 114).
\end{abstract}

Embora os autores tenham conceituado essa estrutura de relação entre produtor e espectador, consideram que exista uma disjunção entre os contextos de produção e de recepção, pois o produtor não está presente no momento em que a recepção visualiza a representação, impossibilitando uma resposta direta de um para o outro. Assim, consideram como interação o envio, por parte do produtor, e o recebimento, por parte do espectador. Porém, chamam atenção para o fato de que ambos compartilham a "linguagem" que permite a produção da representação, por parte do produtor, e a construção de um sentido para a imagem utilizada na representação, por parte do espectador.

\footnotetext{
${ }^{6}$ Nossa tradução para: "Interactive participants are therefore real people who produce and make sense ofimages in the context of social institutions which, to different degrees and in different ways,regulate what may be 'said' with images, how it should be said, and how it should be interpreted. In some cases the interaction is direct and immediate. Producer and viewer know each other and are involved in face-to-face interaction..."
} 
O sistema semiótico envolvido, que reflete um contexto sociocultural específico, faz parte do conhecimento linguístico dos dois participantes. $\mathrm{O}$ autor da imagem a produz para um tipo de leitor específico, que tenha conhecimento do sistema semiótico, da linguagem utilizada, mesmo que seja um conhecimento inicial, que possa ser aprimorado através do uso. Quanto mais representações que envolvam o sistema em questão forem lidas, maior será a chance de que o leitor compreenda tais composições, podendo, inclusive, estabelecer relações entre elas, de modo a aumentar a potencialidade da construção de sentido para o texto/representação em questão.

Com relação à perspectiva, Kress e Van-Leeuwen (2006) dividem as imagens em dois tipos: a) objetiva, sem uma perspectiva central e geralmente associada a representações científicas e técnicas; e b) subjetiva, com uma perspectiva central, na qual o ponto de vista do espectador é dado pelo produtor da imagem. A representação com perspectiva subjetiva pode subentender uma relação entre imagem e espectador, inclusive de poder de um sobre o outro. Por exemplo, uma imagem que represente pessoas vistas de cima dá ao espectador uma sensação de superioridade em relação aos participantes ali representados.

A distribuição espacial dos elementos lhes confere valor a partir do momento em que elementos colocados à direita são chamados de Novos pelos autores. Já os elementos à esquerda são os Sabidos, que já fazem parte do conhecimento do leitor sobre o assunto, sendo informações culturalmente conhecidas. Com relação ao eixo vertical, os elementos que aparecem na parte superior da composição são chamados de Ideais, representantes do planejamento que se tem com relação ao todo. Por sua vez, os elementos já existentes estão localizados na parte inferior da composição e representam as informações objetivas, as instruções, os detalhes essenciais. Essa é uma composição essencialmente ocidental e polarizada. Os autores apresentam também composições de estilo oriental (mais comuns atualmente), nas quais um elemento central é considerado núcleo da informação, o Centro, e os elementos que estão dispostos ao redor deste, as Margens, estão subordinados e são elementos dependentes do elemento central, não havendo diferença de valor entre uns e outros.

O realce de alguns elementos demonstra sua importância em relação a outros, quando aparece mais nítido, ou com cores mais fortes, ou em primeiro plano, destacando-se dos demais. Com relação ao enquadramento, os autores observam que, algumas vezes, os elementos que fazem parte da composição podem aparecer juntos ou "separados" de alguma forma, por exemplo, em uma foto na qual cada pessoa esteja olhando para um lado, ou entre as quais exista 
um poste, um carro etc. (elas não parecem juntas na imagem, embora façam parte da mesma cena, pois estão desconectados).

A análise da composição é particularmente importante para o estudo de textos que contenham mais de um sistema semiótico, os textos multimodais. A posição de Kress e Van Leeuwen (2006) com relação a esses textos é de que devem ser vistos como um todo integrado, no qual os elementos de cada sistema se alteram na conexão que estabelecem uns com os outros no processo de produção do sentido.

\section{Metodologia}

A pesquisa foi realizada a partir da análise da interface do LOL, de fóruns do site oficial do jogo no Brasil (forum.br.leagueoflegends.com) e de interações entre jogadores no grupo fechado League of Divas, do Facebook, por meio de comentários em postagens. Também buscamos informações, no site oficial, a respeito de como a desenvolvedora, a RIOT Games, apresenta o jogo para seus prossumidores, construindo espaço para o letramento remix.

Conversas informais com jogadores que fazem parte de nosso grupo de amigos e familiares também foram bastante esclarecedoras quanto à dinâmica do jogo e às suas regras, sendo cruzadas com o demais conjunto de dados para melhor compreensão da dinâmica do letramento digital e remix no LOL. Finalmente, assistimos a gameplays no YouTube e lives na TwitchTV. Todas as amostras coletadas nesses espaços e práticas são escolhidas e aqui mobilizadas em função de nosso objetivo de discutir algumas dinâmicas implicadas na cultura remix que envolve o LOL, considerando como critério a utilização de exemplos que consideramos mais representativos do conjunto de materiais que compõem nossa coleção de dados.

\subsection{O jogo League of Legends}

O LOL foi desenvolvido pela RIOT Games e lançado nos Estados Unidos em 2009. No Brasil, o lançamento foi em 2012, mas antes disso os jogadores já utilizavam a plataforma norte americana para ter acesso ao LOL. Trata-se de um jogo estilo MOBA (Multiplayer Online Battle Arena) ${ }^{7}$, em que dois times, cada um com cinco jogadores, têm como objetivo chegar até a base inimiga e destruir seu Nexus, que é a estrutura responsável pela criação de novas tropas.

\footnotetext{
${ }^{7}$ Estilo de jogo no qual o jogador é responsável pelas ações e decisões de seu personagem, que faz parte de um time, composto por outros personagens controlados por outros jogadores. Os companheiros de time devem se comunicar e estabelecer estratégias para tentar derrotar o time adversário, que é formado da mesma maneira.
} 
Uma vez destruído o Nexus, o jogo se encerra. Ele é gratuito e, de acordo com designers de games e jogadores, inicialmente pode ser considerado "mais simples do que outros MOBAs", pois o novo jogador tem menos opções de campeões e de itens para selecionar e combinar para, aos poucos, ganhar experiência e aumentar sua coleção.

A ação acontece com a intensidade dos jogos de estratégia em tempo real (RTS) e apresenta elementos dos RPGs (role-playing games ${ }^{9}$ ). Cada jogador deve selecionar seu campeão entre cento e quarenta e uma opções, de acordo com a estratégia adotada por seu time, e a ele agregar itens (como Amuleto da Fada ou Arco Recurvo, por exemplo), selecionados de uma coleção de duzentas e setenta e sete opções. As combinações de itens e de campeão devem ser feitas visando o melhor resultado para o time como um todo, e a comunicação com os companheiros de time pode acontecer via chat de voz para aqueles que possuem headset (fone e microfone). Abaixo, podem ser vistas imagens da tela inicial após uma escolha dos campeões ter sido feita.

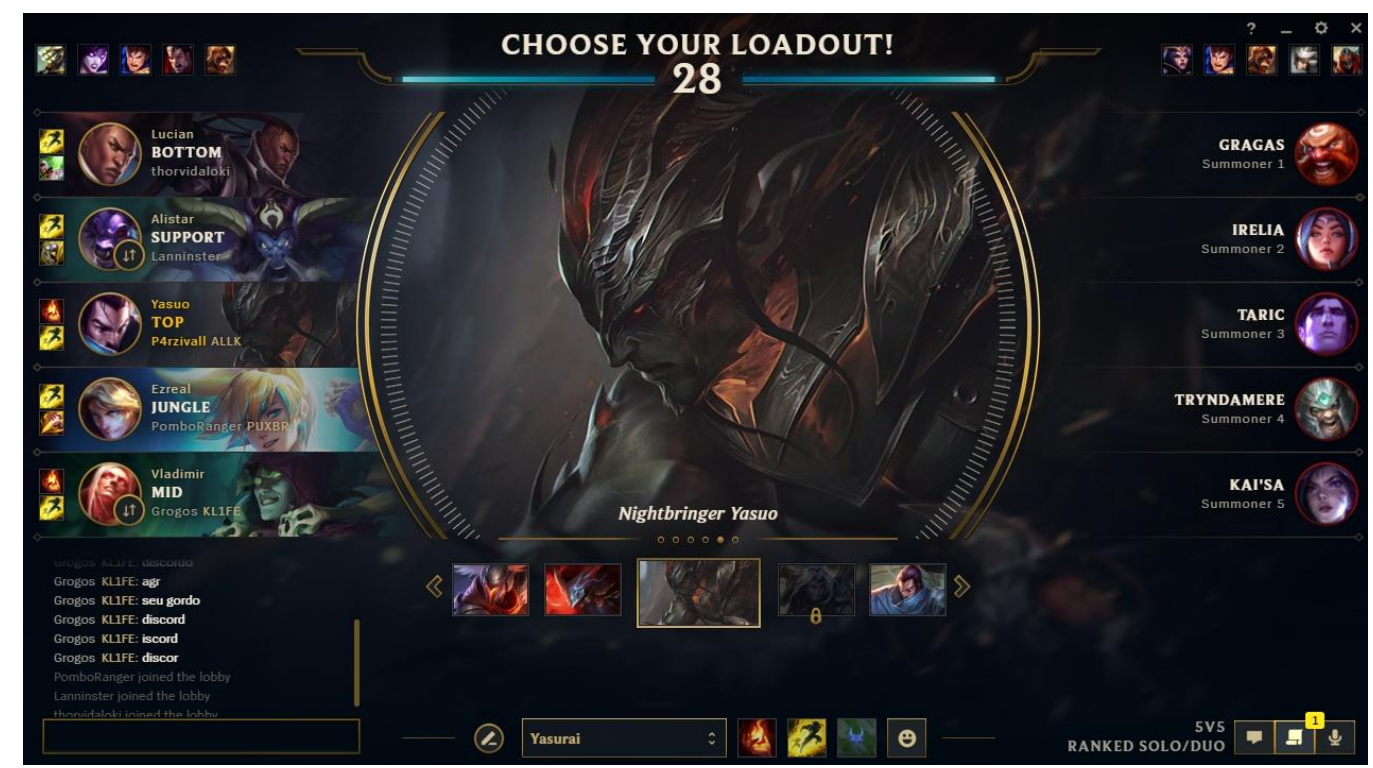

Figura 01: Tela inicial após uma seleção dos campeões. (Fonte: elaboração da autora, Campo Grande, 2018).

A batalha possui três possibilidades de cenário, sendo a mais apreciada aquela que apresenta o modo com cinco jogadores em um mesmo time, conhecida como Summoner's Rift. Nessa opção, o jogador tem três caminhos para chegar até a base inimiga e visualiza seu campeão lutando na maior parte da tela, enquanto acompanha a evolução da partida e o avanço

\footnotetext{
8 NERDCAST. Episódio: 631 - League of Legends: confia na call. Disponível em: https://jovemnerd.com.br/nerdcast/league-of-legends-confia-na-call/ Acesso em: 04 out. 2018.

${ }^{9}$ Jogos nos quais o jogador é quase um ator que encena em cada partida uma peça, como se ele interpretasse seu personagem, com ele ganhando pontos que são transformados em experiência e habilidade, o que faz com que ele evolua. Ficaram conhecidos na década de oitenta, quando eram então, jogos de tabuleiro.
} 
dos companheiros, bem como das tropas inimigas, em um mini-mapa que fica localizado no canto direito inferior da tela. Os três caminhos são chamados bot (de bottom), mid (de middle) e top, respectivamente, o caminho inferior, do meio e do topo do mapa. Além das chamadas lanes (caminhos), um dos campeões do time deve ir pela jungle (selva), localizada entre os caminhos, sendo essa uma estratégia muito utilizada, pois esse jogador fica invisível para o time adversário (a não ser que tenham sido instalados wards, totens de segurança, que funcionam como câmeras para o time que os colocou). Cabe notar que o uso da jungle como espaço de jogo foi criado por um jogador que decidiu aproveitá-lo, o que ilustra a posição de prossumidor do jogador de LOL.

O jogo passa por atualizações, geralmente uma vez por mês, o que contribui para que os jogadores se mantenham interessados. As informações sobre essas atualizações são apresentadas por meio de patchnotes, centradas na escrita, que podem ser acessadas a qualquer momento através de um link que aparece na interface inicial. A leitura dessas patchnotes não é essencial, mas pode ser importante para um bom desempenho durante o jogo, tendo em vista que elas trazem informações sobre alterações no modo de jogo, itens novos e alterados, modificações dos campeões, todos dados que guiam as seleções e combinações utilizadas na partida.

Cada partida dura no mínimo quinze minutos e no máximo uma hora. A qualquer momento o jogador pode trocar os itens de seu campeão, bastando para isso acessar a loja, retornando até a base de seu time; mas não pode trocar de campeão. As mortes do campeão são ilimitadas, mas sempre que renasce ele terá retornado à sua base, dando início a um novo deslocamento em direção à base inimiga.

No site do desenvolvedor do jogo estão disponíveis informações essenciais para um bom desempenho do jogador iniciante, o chamado noob. As regras básicas, explicações sobre os modos de jogo, itens, a biografia de cada campeão, mapas e lendas de Runuterra (universo do LOL em que ocorrem as batalhas) se apresentam em forma de texto, com imagens estáticas ilustrando-os. Também podem ser encontrados vídeos no YouTube de canais oficiais do LOL (ligados a Riot), que mostram partes da história dos campeões e relações de uns com os outros, informações sobre atualizações, divulgação do jogo e afins. Além desses vídeos, o jogador também pode aprender mais sobre LOL assistindo aos chamados streamings, que são vídeos disponíveis ao vivo e posteriormente armazenados em bibliotecas. Além dos vídeos que mostram estratégias e combinações de campeões e itens, a Twitch.tv também transmite os campeonatos de LOL, finais e fases eliminatórias. 
Também no site da Riot há um espaço no qual fóruns com diversos temas podem ser acessados por qualquer um. São murais com temas como "avisos e novidades", "e-sports", "suporte", "League of Legends", cada um com 2 ou mais subtemas, separados por assuntos como "novos jogadores", "mecânica do jogo", "arte, música e história”. Dentro de cada subtema, os usuários podem iniciar fóruns como "melhores campeões para subir de elo", "aulas para iniciantes", "montando time de jogadores iniciantes" etc.

\section{Análises}

Inicialmente, observamos que a desenvolvedora do jogo o apresenta aos prossumidores de forma quase didática, com um número reduzido de elementos a serem combinados (itens e campeões), a possibilidade de treinar antes em um tutorial (jogo solo) e uma simulação de batalha, na qual os campeões do time adversário são controlados pelo sistema. Todas as informações são fornecidas através de textos e de vídeos curtos que mostram o funcionamento de cada campeão.

Um grande número de informações adicionais pode ser encontrado no site do jogo, para que o prossumidor possa aumentar seu conhecimento sobre cada campeão, pois suas origens e relações com outros personagens podem ser decisivas na escolha de itens, bem como de estratégias. A ferramenta principal para que o jogador tenha acesso e explore essas informações é a navegação através da lincagem, e os sistemas semióticos envolvidos são imagens estáticas e em movimento (vídeos curtos), sempre permeadas pela escrita. Abaixo, pode ser observada a imagem na qual o jogador visualiza os itens dispostos em taxonomia encoberta, disponíveis para seleção.

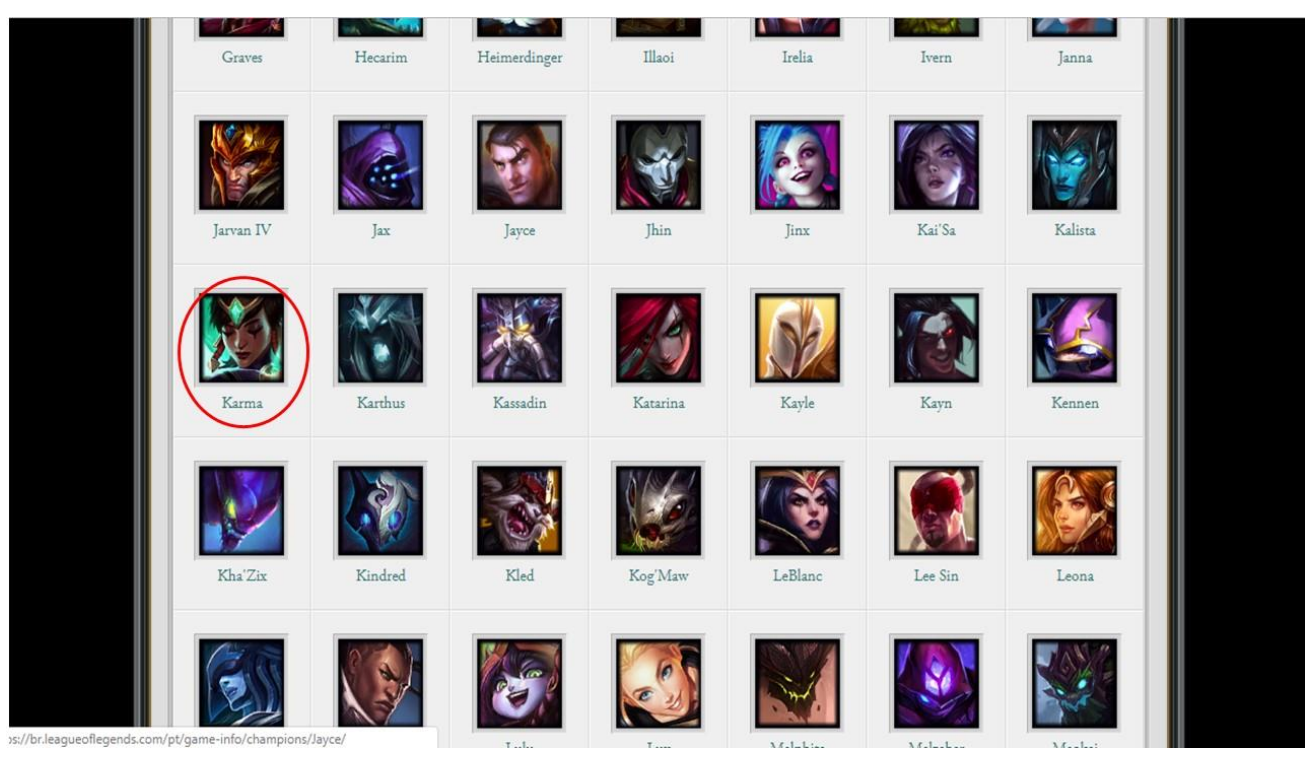


Imagem 02: Tela na qual o jogador pode escolher entre mais de 140 opções de campeão, grifado em vermelho a campeã Karma, que através da lincagem, dá acesso a imagem 08. (Fonte: <https://br.leagueoflegends.com/pt/game-info/champions/> Acesso em: 10 fev. 2019).

Ao escolher um(a) dos campeões(ãs), o jogador é direcionado para uma nova tela, por lincagem. Nessa nova tela, repete-se a taxonomia encoberta, que aparece como a forma principal de classificação das imagens de LOL. Supondo que o jogador tenha escolhido a campeã Karma, ele poderá clicar em um novo link disponível na tela, "Explore a história de Karma" sendo direcionado para uma terceira tela (imagem 03, a seguir), na qual outros links surgem como opção para ampliar seu conhecimento sobre essa campeã. A lincagem pode continuar, de acordo com a seleção realizada pelo prossumidor. Na imagem 08, observamos uma perspectiva objetiva e uma composição visual oriental, na qual o centro apresenta o Núcleo da informação e nas Margens podem ser vistos elementos subordinados e dependentes dele, mas que não estão dispostos de forma hierarquizada.

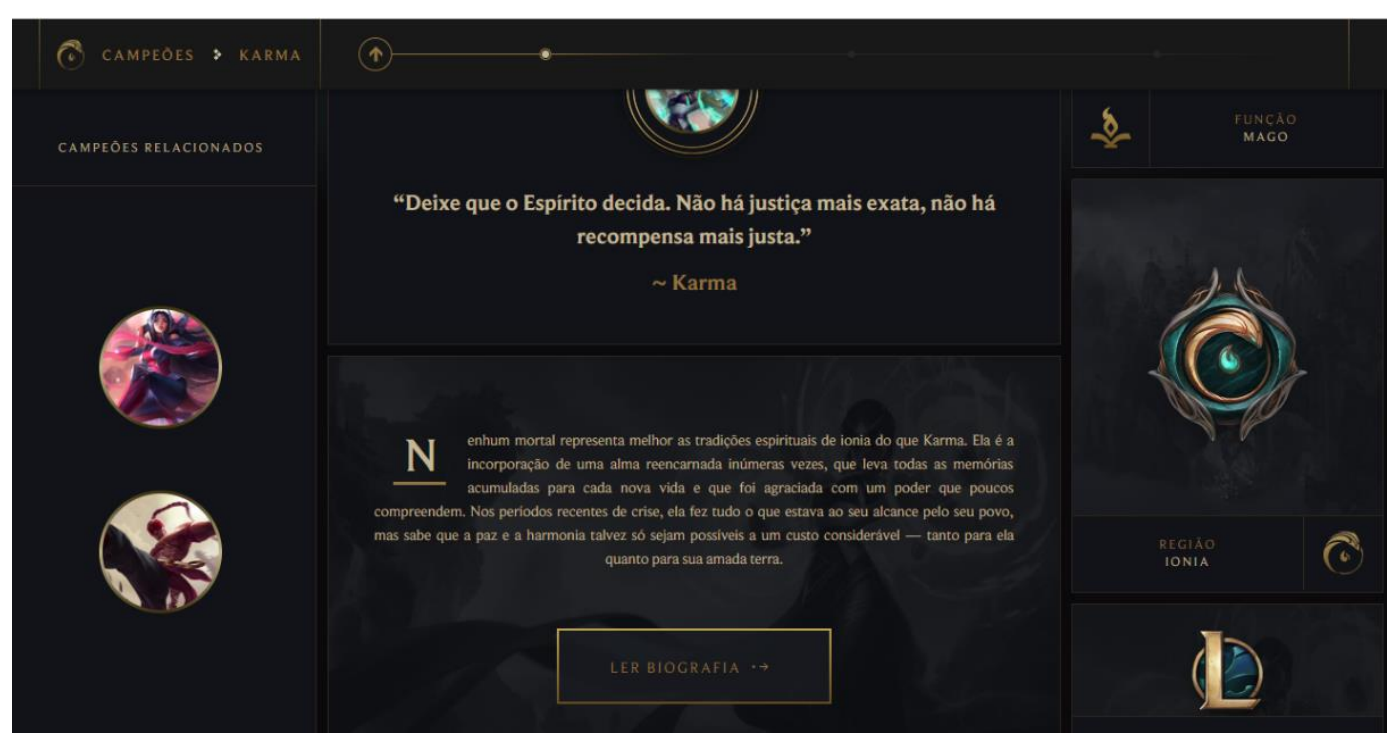

Imagem 03: Tela do link da anterior, na qual se observa a dica de conhecer os campeões relacionados a Karma, bem como a possibilidade de ler mais sobre ela. Também é possível conhecer mais sobre a região do mundo fictício Runuterra, origem de Karma (clicando em "Região: Ionia). (Fonte: <https://universe.leagueoflegends.com/pt_BR/champion/karma/> Acesso em: 10 fev. 2019).

Embora nessas interfaces obtidas por meio de lincagem no site do LOL a produção de sentidos se dê via imagem-escrita, nos fóruns encontrados no site oficial as interações ocorrem fundamentalmente por meio da escrita, podendo-se verificar na imagem 04, abaixo. De todo modo, o letramento grafocêntrico, nesse caso, conecta-se ao letramento em SMS, pela utilização do internetês, de emoticons etc. 


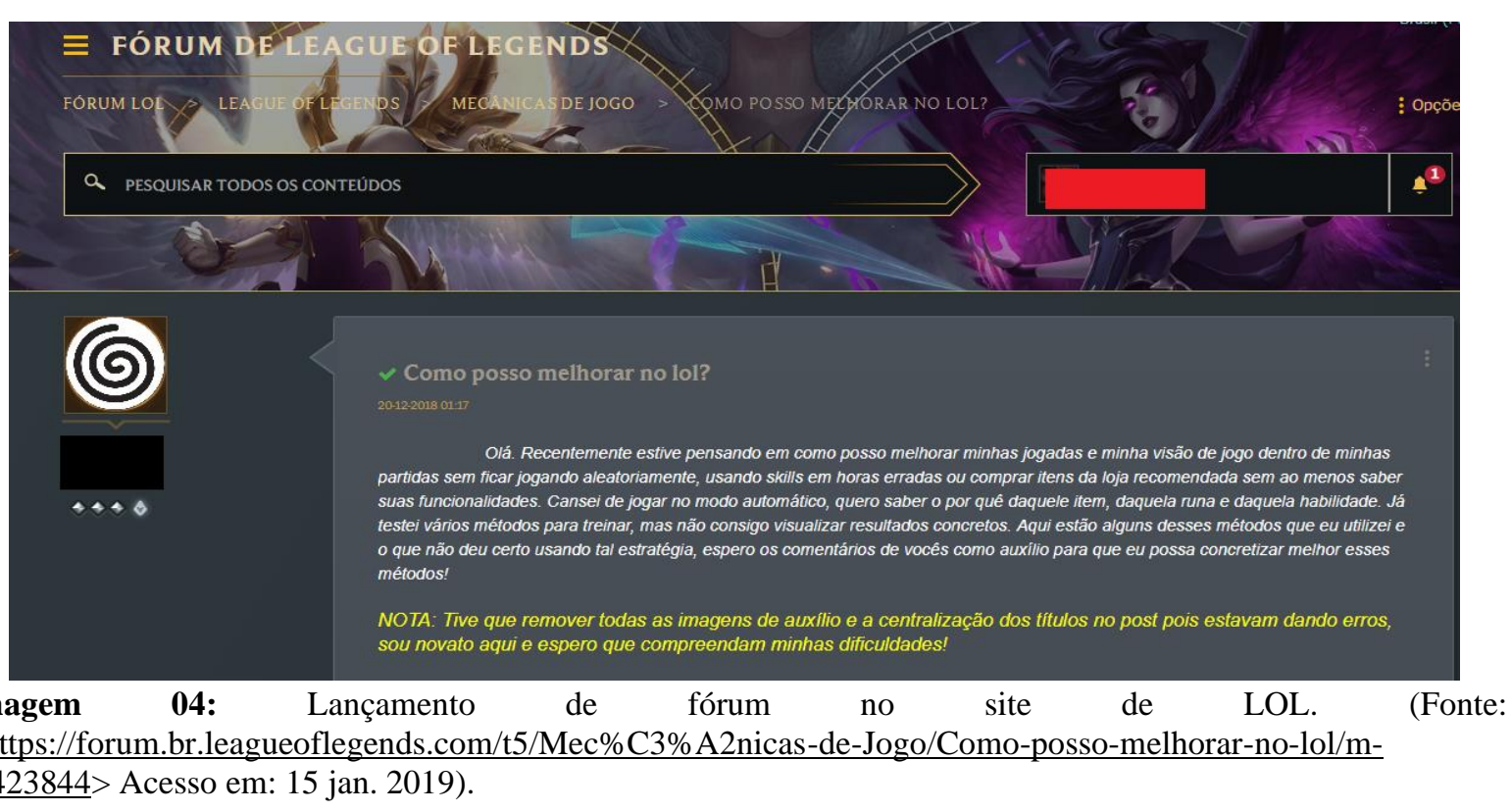

Vemos, então, que o jogador já assume seu papel como prossumidor ao escolher de que forma quer aprender sobre o jogo, lendo as regras e participando dos fóruns no site, assistindo a gameplays no YouTube, assistindo a streamers ou jogando. Parece-nos importante observar que os próprios jogadores sugerem essas formas de aprender, de acordo com as respostas à questão inicial do fórum analisado (foram encontrados outros com o mesmo tipo de pergunta, sendo observado o mesmo estilo de reposta).

Consideramos o processo de seleção como estratégia de consumo utilizada pelo jogador, e a combinação como estratégia de produção, o que nos faz pensar no jogador do LOL como um prossumidor. Verificamos que é possibilitado a ele que mescle, durante todo o processo de seleção e combinação, a escrita grafocêntrica e as imagens, bem como que possa agregar vídeos à sua experiência com o jogo.

Durante a partida, o prossumidor pode alterar os itens por ele selecionados inicialmente, pois, conforme o andamento do jogo, as estratégias do time podem ser modificadas, exigindo rapidez na leitura dos dados e na tomada de decisão. As habilidades ligadas aos letramentos digitais são essenciais para a eficácia na performance do jogador, que deve relacionar imagem e escrita o tempo todo. Isso também se dá porque a comunicação entre os jogadores, de mesmo time ou de times opostos, ocorre através do chat, que pode ser visto na hud à esquerda da tela, e demanda o "letramento em SMS" de Dudeney et al (2016). Na imagem 05, estão demonstradas e assinaladas as huds utilizadas pelo prossumidor/jogador durante uma partida de LOL. 


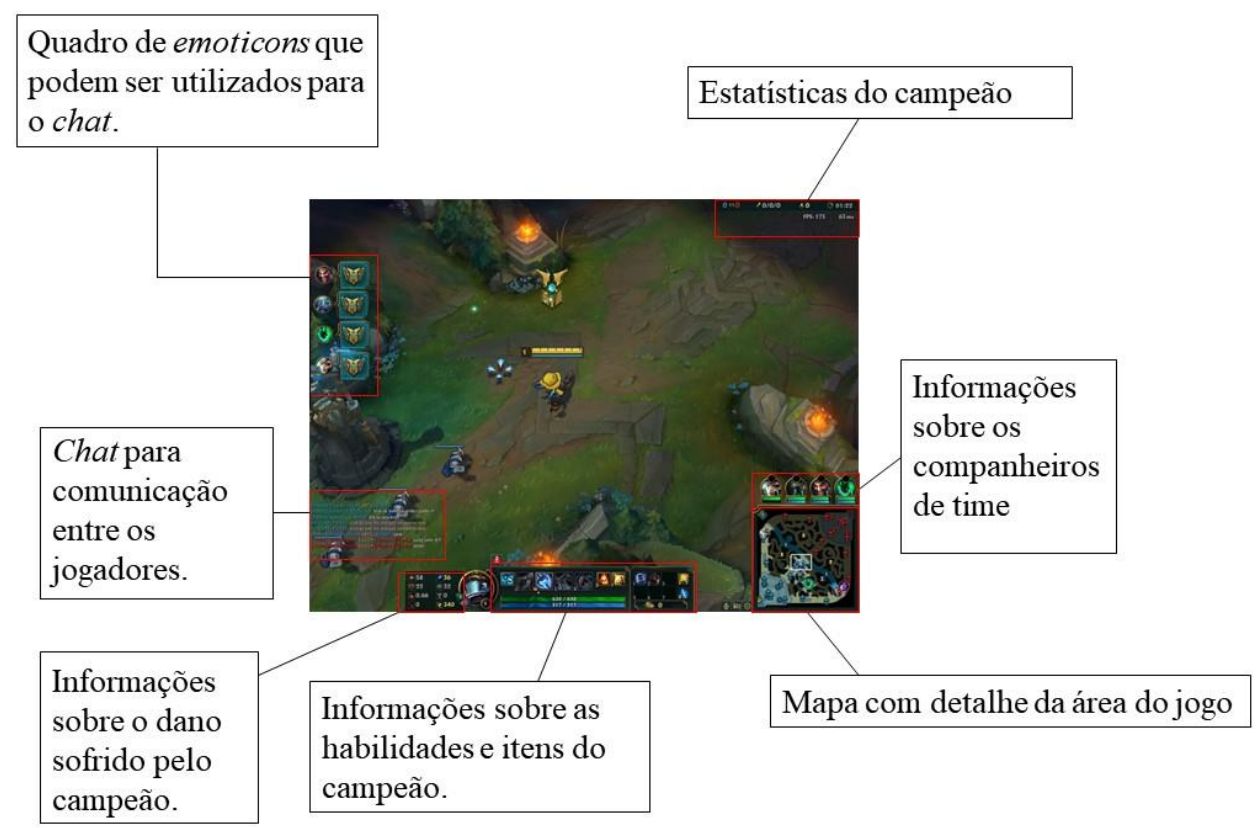

Imagem 05: Captura da tela durante a partida, com especificação da hudes. (Fonte: elaboração da autora, Campo Grande, 2018).

$\mathrm{Na}$ imagem, percebemos que a tela de LOL é uma estrutura representacional narrativa em movimento, cujo vetor de ação que liga os interatores é o próprio cursor, pois o prossumidor demarca com ele a área alvo do disparo, ao mesmo tempo em que direciona o movimento de seu campeão. A tela pode mostrar a parte do todo onde se encontra o campeão ou uma parte do todo selecionada pelo prossumidor - câmera travada e câmera solta, respectivamente. De acordo com a desenvolvedora, a câmera travada faz parte de um processo inicial, até que o prossumidor se sinta confortável para ler o todo do jogo em áreas nas quais ele não se encontra, acompanhando sua movimentação através da hud localizada no canto inferior direito da tela (mini mapa), ao mesmo tempo em que visualiza os movimentos mais detalhados dos companheiros de time ou do time adversário, ampliando, assim, os letramentos envolvidos na partida.

No jogo, as ações projetivas dos processos verbais não acontecem através de balões, mas na forma de áudio, por meio dos quais o campeão se comunica somente com o jogador que o escolheu. Além disso, processos mentais podem ser observados, como no caso do campeão deficiente auditivo, que "se comunica mentalmente" com seu jogador. As falas dos campeões podem ter seu idioma alterado: o jogador escolhe se quer ouvir os diálogos em português, inglês, chinês, japonês, espanhol, francês etc., o que indica participação na dinâmica do jogo. Com relação às circunstâncias, observamos que o cenário se apresenta menos nítido, ficando 
em segundo plano, de forma a dar mais destaque para os personagens, seus instrumentos de ação (itens) e eventuais acompanhantes comandados pelo próprio sistema do jogo (cf. imagem $05)$.

Sendo a interface do LOL um sistema multimodal, a composição é essencial na construção de sentido. Temos, pois, o elemento principal (o campeão) no centro da tela, e informações essenciais ao redor (as huds, imagem 05). Se optar por travar a câmera, o prossumidor valora sua ação como principal, mas com a câmera solta ele transfere a importância a outros elementos do sistema. Já a perspectiva subjetiva, que pressupõe uma relação entre a imagem e o espectador, transmite a superioridade do jogador/espectador, que observa a imagem de cima. Porém, sendo ele prossumidor, pode ser considerado produtor e espectador, o que nos leva à ideia de produtor primário, a desenvolvedora do jogo, e produtor secundário, o jogador, que domina o sistema semiótico a ponto de conseguir redesenhar a partir da base inicial.

O redesenho é uma estratégia constante em LOL, inclusive por parte da RIOT, que anualmente faz uma atualização do jogo, a chamada season. Tal atualização não tem como objetivo corrigir possíveis erros ou melhorar determinados elementos, pois tais ações podem ocorrer a qualquer momento, desde que sejam necessárias: "nossa intenção é manter o jogo crescendo, para que você possa descobrir novas técnicas" (Canal de Aprendizado, League of Legends BR/YouTube, 2016). O “erro" não é visto como algo negativo (“às vezes cometemos erros, mas estamos sempre olhando pra eles pra continuar evoluindo o League" (idem)), mas sim como parte do percurso evolutivo do jogo, sendo essa uma ideia que passa para o prossumidor, que se sente livre para arriscar repensar estratégias e redesenhar o jogo.

O incentivo ao redesenho por parte do prossumidor é tão grande, que a possibilidade de mudanças na forma de jogar são aproveitadas pela RIOT, como o uso do setor chamado jungle, que inicialmente fazia parte do cenário, até que, em 2012, Danil "Diamondprox" Reshetnikov, um jogador russo profissional, revolucionou essa área, fazendo com que ela funcione quase como outro caminho (lane), inclusive contando, atualmente, com campeões específicos para esse terreno. Outro exemplo da relação de parceria que existe entre produtor e prossumidor é o caso de um item que, após ser lançado pela RIOT, sofreu alteração quase imediata após a sugestão de um jogador: "Ok nós concordamos. Apenas nos dê um ou dois patches e isso será feito" 10 , foi a resposta da desenvolvedora, e pouco tempo depois a alteração já havia sido publicada em um fórum oficial do servidor americano.

\footnotetext{
${ }^{10}$ Rioter (funcionário da RIOT), em resposta a sugestão do jogador em um subreddit, que é um tópico dentro do aplicativo Reddit, bastante utilizado por jogadores de LOL para troca de informações.
} 
O letramento remix, associado ao redesenho, também é uma prática da própria RIOT que pode ser observado nas referências existentes em skins $^{11}$ temáticas ou especiais. Algumas referenciam diretamente outros jogos, como os antigos fliperamas e animes, outras são comemorativas de eventos como o Natal, o ano novo chinês, o Carnaval, o dia dos namorados etc. Muitas delas são baseadas em sugestões dos jogadores, assim como alguns campeões que se parecem muito com um conjunto de sugestões que são dadas nos fóruns, páginas, no site Reddit $^{12}$ e em outras mídias. As histórias dos campeões são também contadas em muitos gêneros, uma vez que são utilizados vídeos, contos, poemas e quadrinhos para engajar o jogador a partir de seus personagens favoritos. Nas imagens 06 e 07, podem ser observadas algumas skins que se constituem como remixagens da história infantil "Chapeuzinho Vermelho" e homenagens a culturas de muitos países com "El Tigre”, respectivamente.

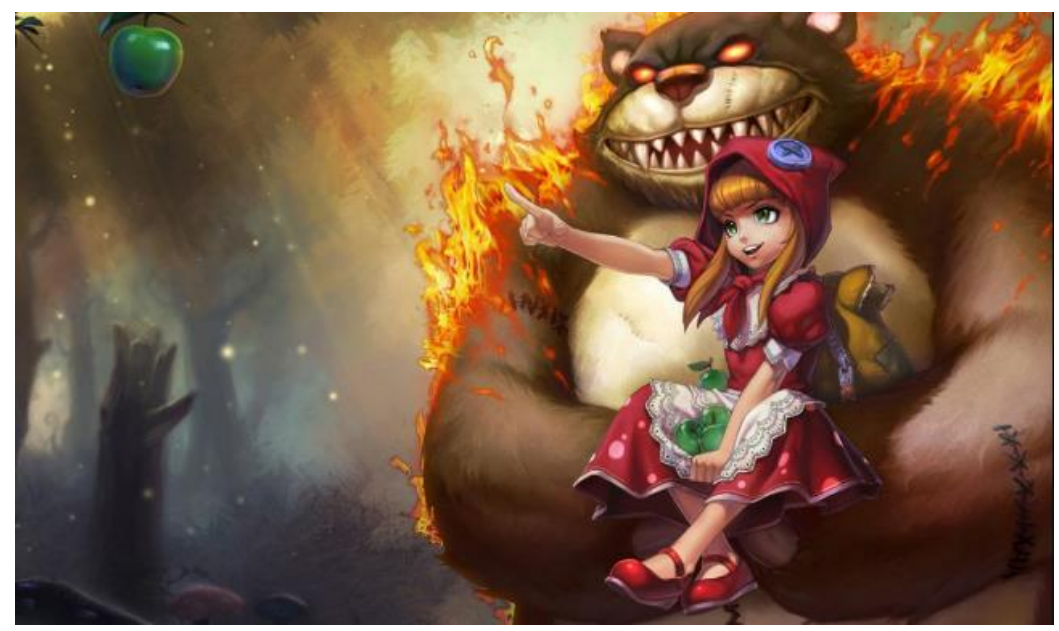

Imagem 06: Campeã Annie com skin Chapezinho Vermelho, captura da tela do site de League of Legends. (Fonte: <https://ddragon.leagueoflegends.com/cdn/img/champion/splash/Annie_2.jpg>Acesso em: 15 abr. 2109).

\footnotetext{
${ }^{11}$ Skin pode ser traduzida como o traje do campeão, que, incialmente é o original, mas depois pode ser trocado por outro adquirido na loja virtual, usando créditos comprados mediante pagamento online, ou como premiação por um nível atingido ou sorteio.

${ }^{12} \mathrm{O}$ Reddit é um site no qual o usuário estabelece ligações de determinado conteúdo com outros, de acordo com a sua valoração dos mesmos, usando o letramento digital classificatório e a estratégia da folksonomia, anteriormente já mencionados. O usuário redesenha o conteúdo, através das conexões que percebe nele.
} 


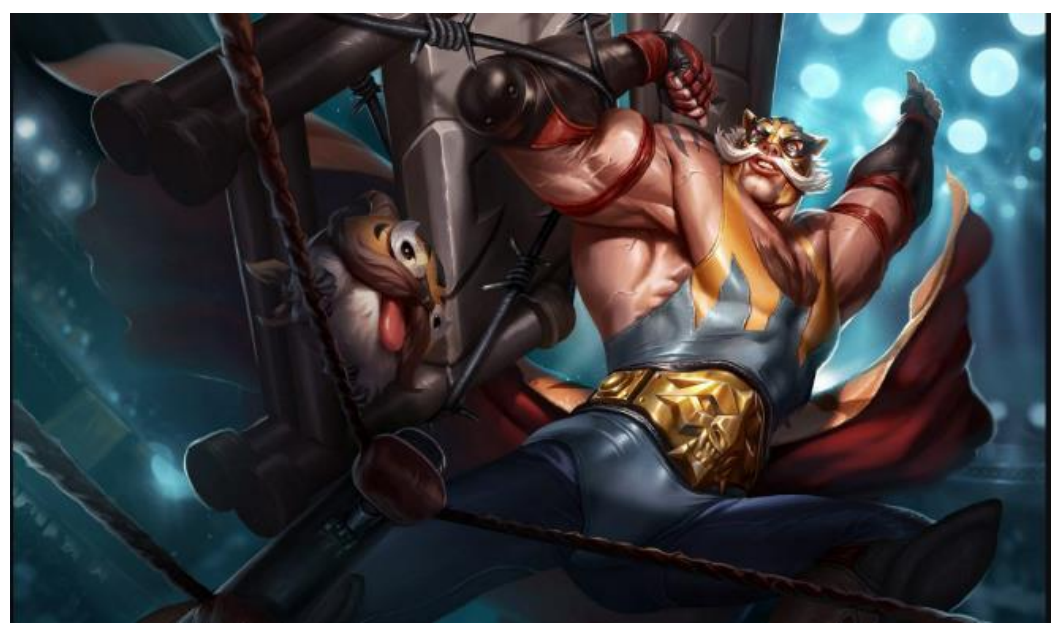

Imagem 07: Campeão Braun com skin El Tigre, captura da tela do site de LOL. (Fonte: <https://ddragon.leagueoflegends.com/cdn/img/champion/splash/Braum_2.jpg> Acesso em: 15 abr. 2019).

Além de muitos sistemas semióticos, a desenvolvedora oferece informações complementares sobre seu universo e personagens através de diversos gêneros literários. Em todos os sites oficias (Estados Unidos, México, Brasil etc.) podem ser encontrados contos, cânticos e história em quadrinhos, cada um em sua língua nativa. Alguns exemplos do site brasileiro podem ser observados nas imagens 08 e 09, que remetem ao cântico e à história em quadrinhos, respectivamente.

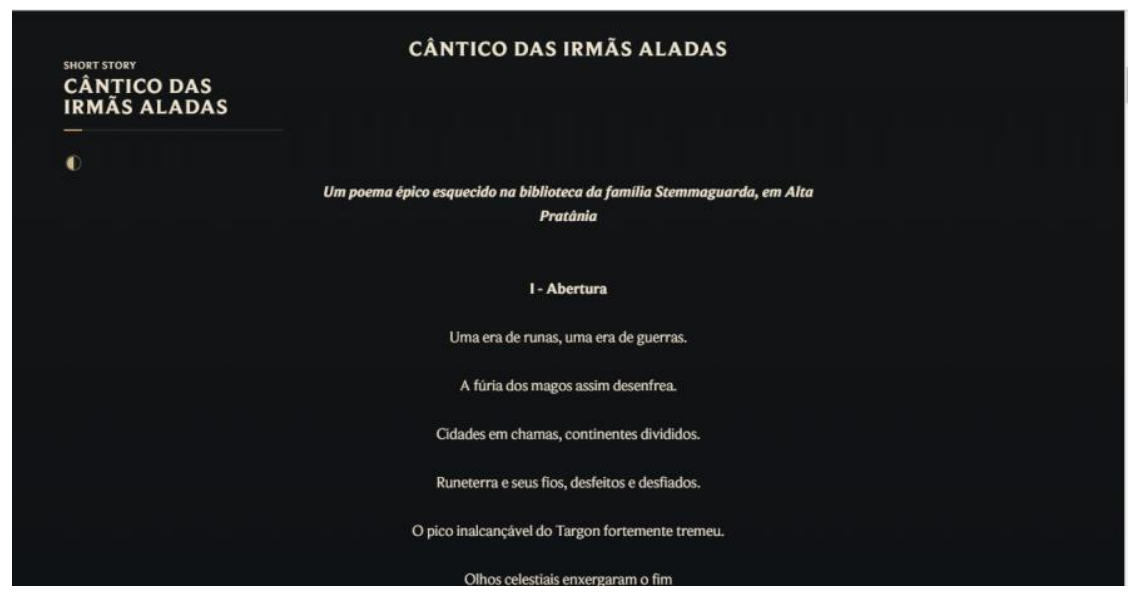

Imagem 08: Exemplo do gênero lírico do site de LOL (captura de tela). (Fonte: <https://universe.leagueoflegends.com/pt_BR/story/canticleofthewingedsisters/>Acesso em: 10 abr. 2019). 

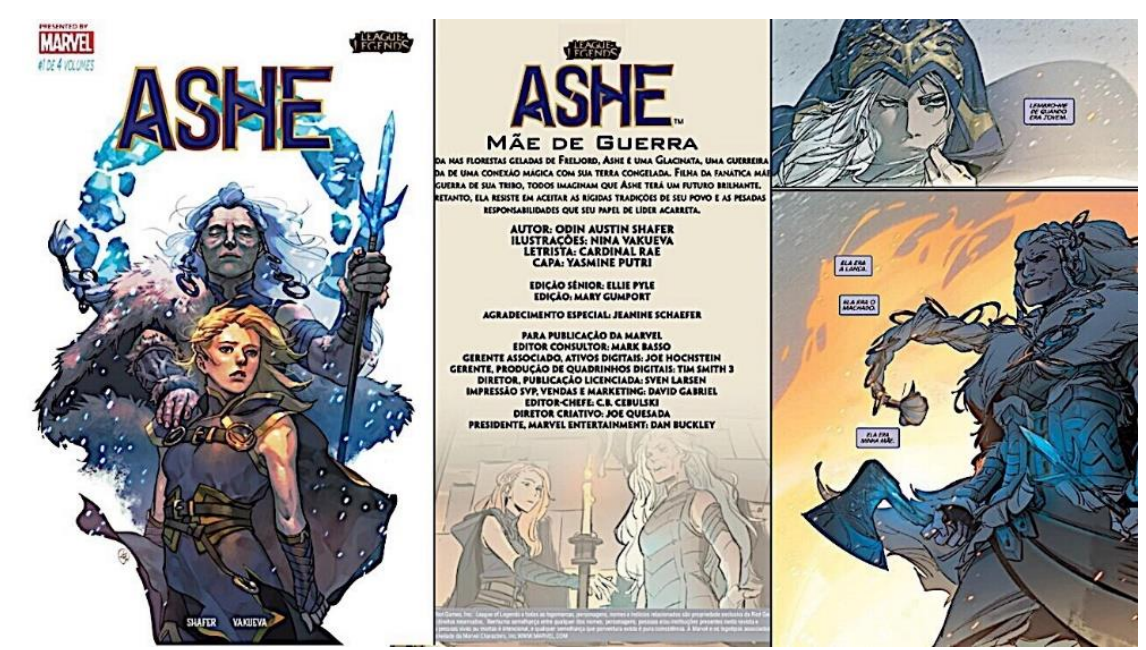

Imagem 09:

exemplo

do

gênero

quadrinhos

<https://universe.leagueoflegends.com/pt_BR/comic/ashewarmother/issue-1/0/>Acesso em: 10 abr. 2019).

O letramento remix também se evidencia na análise de algumas postagens da página do grupo fechado League of Divas, da mídia social Facebook, que se mostra um espaço muito efetivo quanto a trocas de dicas, experiências e estratégias entre os jogadores. O grupo é fechado porque o moderador só aceita mulheres e pessoas LGBTQ, com a prerrogativa de se protegerem contra o machismo, a homofobia e a transfobia que, segundo eles, rondam o LOL - assim como ocorre em outros espaços virtuais, onde muitos se sentem confortáveis para manifestações de ódio, escondidos atrás das telas.

Algumas postagens dos membros do grupo têm início com memes ${ }^{13}$, perguntas no estilo pesquisa de opinião, textos e desenhos produzidos e remixados por eles mesmos e compartilhados, ou somente com afirmações. Entretanto, ao analisarmos os comentários, percebemos que essas postagens podem acabar se tornando fonte de troca de estratégias e dicas de jogo, passando, muitas vezes, por um redesenho de sua função inicial, para uma secundária, o letramento no jogo. Observa-se, inclusive, o remix através de conexões/inferências com outros filmes, programas, personagens etc., fazendo dele uma via de mão dupla: o texto inicial foi redesenhado, mas aquele que se relaciona a ele nesse processo também passa por uma transformação.

Nas imagens abaixo, observamos primeiramente um post que mobiliza a personagem Collete, do filme Ratatouille, e a reconfigura a partir da campeã do LOL Fiora, evidenciando a remixagem e o "caminho aberto" de possibilidades que configura a cultura remix e a cultura do LOL. Na sequência (imagem 11), temos um comentário que se relaciona ao post anterior,

\footnotetext{
${ }^{13}$ Meme é uma imagem, vídeo ou GIF, geralmente humorística, que se torna viral na Internet.
} 
construindo sentidos que remetem ao filme e à campeã mencionados, mas englobam uma terceira referência: o popular programa televisivo "Master Chef".

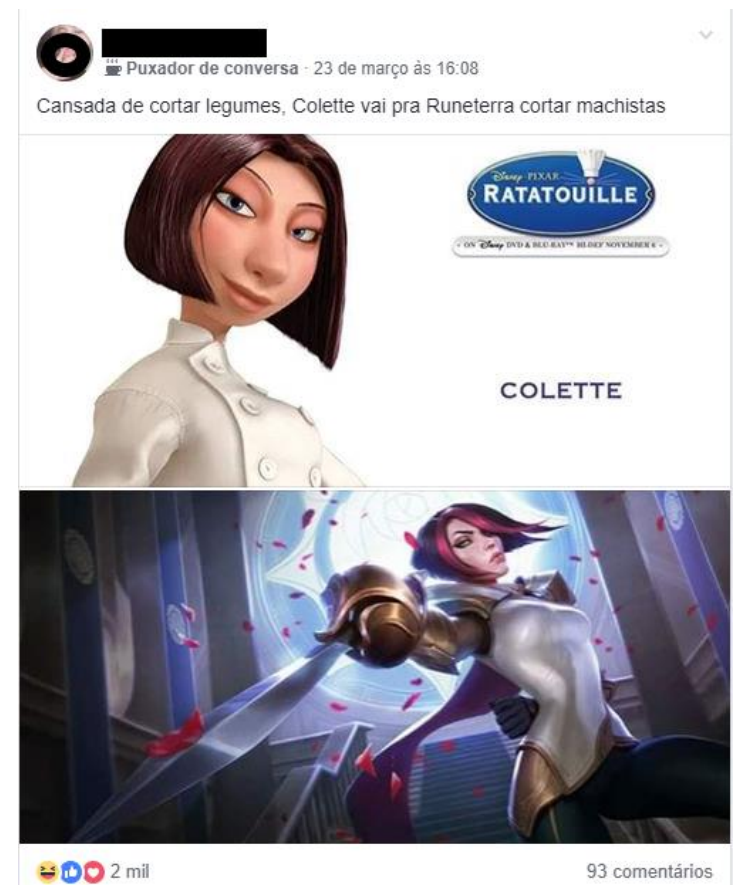

Imagem 10: Postagem sobre a campeã Fiora, que, de acordo com seu autor, se parece fisicamente com a personagem Colete, da animação "Ratatouille" (Disney).

Fonte: 〈https://www.facebook.com/groups/DivasOficial/permalink/2430904617128525/>

Acesso em: 13 mai. 2019.

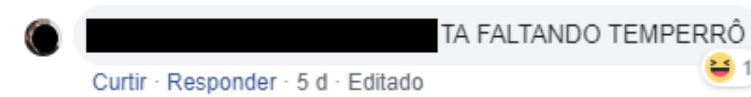

Imagem 11: Comentário relacionando à postagem da imagem 23 com o programa televisivo Master Chef (a personagem Colete é chef de cozinha).

Fonte: <https://www.facebook.com/groups/DivasOficial/permalink/2430904617128525/>

Acesso em: 13 mai. 2019.

Como se verifica nos exemplos selecionados para esta análise, a cultura do LOL evoca o letramento digital e envolve uma rede de letramentos, com destaque para o remix, apontando, de algum modo, para o que se tem nomeado como a própria cultura remix. Isso ocorre porque a presença da remixagem e do redesenho são uma constante nesse universo, assim como as relações de referência entre os mais variados tipos de textos, mídias e semioses, todos atuando simultaneamente para a construção de sentidos e construção de subjetividades. Por fim, lembramos que isso pode ser observado não somente a partir de jogadores assíduos de LOL, pois muitas pessoas que não jogam LOL ou já jogaram uma vez ou outra também conhecem os 
campeões e as suas as histórias, escrevem fanfics e produzem fanarts sobre ele, como tivemos a oportunidade de evidenciar por meio deste estudo.

\section{Considerações finais}

Pensamos que o remix está intimamente relacionado à habilidade de ressignificar, inerente a um novo tipo de leitor que, mais do que buscar referência e estabelecer intertextualidade, amplia a rede de interações entre os elementos de um sistema semiótico e deste com outros, causando um aumento exponencial na potencialidade da construção do sentido. Não se trata somente de dar um outro sentido. Remixar aqui é visualizar as possibilidades de sentido de um elemento de forma simultânea, sem a necessidade de considerar que um possa ser mais acertado, em detrimento de outro, mas sim que todos os possíveis naquele tempo-espaço colaboram para o processo de significação.

Acreditamos que a popularidade de LOL esteja relacionada com as possibilidades de remixagem que ele oferece, até mesmo para o próprio prossumidor que pode, através do campeão selecionado, experimentar, ainda que virtualmente, várias possibilidades de "ser", assumindo diferentes gêneros e subjetividades. As inferências são constantes, tanto da desenvolvedora quanto dos jogadores, o que também nos parece uma característica desse leitor que se utiliza de muitos sistemas semióticos para ler e escrever textos construídos de muitos modos, demonstrando que os letramentos digitais não acontecem no espaço entre os opostos (digital e analógico), mas na borda onde os mesmos se encontram e se transformam, conforme lembrou Buzato (2007; 2009).

Acreditamos que a predileção desse novo leitor/aluno por textos que contenham inferências relacionadas a uma cultura ou prática social específica, que possam somente ser lidas por aqueles que façam parte de determinados grupos ou circulem nesses espaços (reais ou virtuais), seja mais do que uma estratégia de leitura, como a intertextualidade, por exemplo ${ }^{14}$. Nossa ideia/hipótese é de que esse seja um comportamento de um leitor que consegue circular entre os muitos letramentos, digitais ou não, utilizando na construção do sentido qualquer sistema semiótico que conheça, e passando a ler qualquer texto de uma forma hiper, no sentido de "além da superfície material", estabelecendo links no decorrer da leitura, combinado imagens, sons e outros textos.

\footnotetext{
${ }^{14}$ Processo no qual o leitor estabelece relações de um texto com outros por ele já conhecidos, e usa essa ferramenta para ampliar o sentido do texto que está lendo.
} 
Sendo assim, LOL se mostra uma prática social bastante rica para entender esse novo leitor, pois o jogo é construído em uma base que utiliza muitos sistemas semióticos, com destaque para a imagens, sem deixar de lado o sistema grafocêntrico. Além disso, faz parte do contexto sociocultural de muitos dos nossos alunos, o que faz dele um exemplo potencial do que estamos entendendo por cultura digital e por cultura remix.

\section{Referências}

BUZATO, Marcelo E. K. Entre a fronteira e a periferia: linguagem e letramento na inclusão digital. Campinas, SP: [s.n.], 2007.

BUZATO, Marcelo E. K. Letramento e inclusão: do estado-nação à era das TIC. DELTA Documentação de Estudos em Linguística Teórica e Aplicada, v. 25, n. 1, p.1-38, 2009.

DUDENEY, Gavin; HOCKLY, Nicky; PEGRUM, Mark. Letramentos digitais. São Paulo: Parábola Editorial, 2016.

ESCHENFELDER, Kristin R.; CASWELL, Michelle. Coleções culturais digitais em uma época de reutilização e remixes. In: Anais da $73^{a}$ Reunião Anual da ASIS \& T sobre Navegação em Fluxos em um Ecossistema de Informação-Volume 47. Sociedade Americana de Ciência da Informação, 2010. p. 44.

KNOBEL, Michele; LANKSHEAR, Colin. Remix: A arte e o ofício da hibridização sem fim. Revista de alfabetização de adolescentes e adultos, v. 52, n. 1, p. 22-33, 2008.

KRESS, Gunther. Multimodality: a socia semiotical approach to contemporary communication. New York/EUA: Routledge, 2013.

KRESS, Gunther; VAN LEEUWEN, Theo. Reading images: the grammar of visual design. London/New York: Routledge, 2016.

MANOVICH, Lev. $O$ que vem depois do remix. 2007. Disponível em: https://www.academia.edu/542765/What_Comes_After_Remix. Acesso em: 16 out 2019.

NERDCAST. Episódio: 631 - League of Legends: confia na call. Disponível em: https://jovemnerd.com.br/nerdcast/league-of-legends-confia-na-call/ Acesso em: 04 out. 2018.

RIOT. Disponível em: https://br.leagueoflegends.com/pt/news/riot-games Acesso em: 04 out. 2018.

RIOT. Disponível em: https://www.riotgames.com/en/who-we-are/values Acesso em: 20 out. 2018. 
STANOVSKY, Derek. Remix Racism: The Visual Politics Of The "Alt-Right". Journal of Contemporary Rhetoric, v. 7, n. 2/3, p. 130-138, 2017.

Vídeo: Central de Aprendizagem: tipos de câmera - canal League of Legends BR. Disponível em: <https://www.youtube.com/watch? $\mathrm{v}=$ frNcCF16FDo > Acesso em: 25 mar. 2019.

Vídeo: Central de Aprendizagem: filosofias de design - evolução e clareza. Disponível em: $<$ https://www.youtube.com/watch?v=g9i9XeX-

aSc\&list=PLyUnUXWOBrrGvGUR3KPxkbrtvfYGmScos\&index=20\&t=0s $>$ Acesso em: 25 mar. 2019.

Recebido em 09 de setembro de 2019. Aceito em 17 de outubro de 2019. 